\title{
ADMINISTRAÇÃO POLITICA E OS ESTUDOS ORGANIZACIONAIS
}

\author{
Rômulo Carvalho Cristaldo ${ }^{1}$
}

\section{RESUMO}

Nesse artigo teórico se pretende compreender o campo de conhecimento da administração política a luz dos, e em relação aos, estudos organizacionais. Para tanto, recuperamos os fundamentos epistemológicos da administração política para analisa-los por meio de quatro diferentes modelos interpretativos: os paradigmas sociológicos de Burrell e Morgan; as metanarrativas nos estudos organizacionais segundo Michael Reed; o círculo de matrizes epistêmicas de Ana Paula P. de Paula; e a matriz das abordagens críticas em gestão de Thomas Klikauer. 0 método empregado foi a revisão sistemática de literatura. Ao final, chagamos ao entendimento de que, diferentemente do que defendem os propositores do campo, a Administração Política se aproxima do funcionalismo, se valendo de uma narrativa da justiça, por meio de uma abordagem sociológica híbrida e proporcionando não mais do que uma abordagem crítica reformista.

Palavras-Chave: Administração política; Estudos organizacionais; Epistemologia da administração.

\section{LA ADMINISTRACIÓN POLITICA Y LOS ESTUDIOS ORGANIZACIONALES}

\section{RESUMEN}

Este paper teórico tiene el objetivo de analizar el campo de saber de la administración política a luz de los estudios organizacionales. Hacemos una revisión de sus fundos epistemológicos a través de cuatro modelos diferentes de estudios organizacionales: los paradigmas sociológicos

\footnotetext{
1 Professor do Mestrado Profissional em Administração Pública em Rede Nacional (Profiap-UFGD). Professor Ajunto da Faculdade de Administração, Contabilidade e Economia da Universidade Federal da Grande Dourados (FACE-UFGD). Doutor em Administração (NPGA-UFBA), Mestre em Administração (NPGA-UFBA), Bacharel em Administração (EAUFBA).
} 
de los estudios organizacionales de Burrell y Morgan. El modelo de metanarrativas creado por Michael Reed. El círculo de las matrices epistémicas de Ana Paula P. de Paula. Y, la matriz de los estudios críticos de gestión de Thomas Kilikauer. El método utilizado en la investigación fue la revisión sistemática de la literatura. Llegamos a la conclusión de que, contrariamente a lo que afirman los autores de la administración política, se trata de un campo funcionalista, constituido como una narrativa de la justicia, que aparece como un enfoque sociológico híbrido y bajo una crítica reformista.

Palabras clave: Administración política; Estudios organizacionales; Epistemología de la administración.

\section{POLITICAL ADMINISTRATION ANDTHE ORGANIZATIONAL STUDIES}

\section{ABSTRACT}

This theoretical paper aims to examine the political administration's field of knowledge in the light of the organizational studies. It was performed a review of the epistemological aspects of political administration analyzing it through four different models. The first one was the sociological paradigms in organizational studies by Burrell and Morgan. The second is the model of metanarratives in the organizational studies by Michael Reed. Third, the circle of epistemic matrices of Ana Paula P. de Paula. Then, the matrix of critical of management studies from Thomas Klikauer. The method used in the research was the systematic literature review. We concluded that, contrary to what the authors of political administration assert, it is a functionalist field, which uses a narrative of justice, appears as a hybrid sociological approach, thus delivering a reformism criticism.

Keywords: : Political administration; Organizational studies; Epistemology of management.

\section{INTRODUÇÃO}

0 movimento da "administração política" (SANTOS, R. et al, 2017, p. 940) surgiu na Escola de Administração da Universidade Federal da Bahia (EAUFBA) a partir dos anos 2000 com o intuito de se consolidar como uma alternativa de pensamento crítico da administração 
(AMARAL; MONTEIRO; ALMEIDA, 2015). As primeiras formas de manifestação desse conceito remontam a um texto da década de 1990 de R. Santos e Ribeiro (1993). Ali os autores se referiam à "administração política" como um fenômeno concreto e histórico — a administração política do Estado - , argumentando que aquele deveria ser um objeto a ser estudado pela administração. Mais adiante, R. Santos, Ribeiro e T. Santos (2009) passam a apresentar a administração política com um campo de conhecimento, o qual possuiria, a seu ver, objeto e método próprios. E mais adiante a administração política iria ganhar outra forma de manifestação, dessa vez como se fosse uma estratégia de desenvolvimento para o Estado, tal qual aparece no artigo de opinião de R. Santos e Gomes (2017).

São três, portanto, as manifestações principais do conceito de administração política: (i) fenômeno, (ii) campo de conhecimento e (iii) estratégia de desenvolvimento. A proposta desse artigo é analisar essa segunda forma de manifestação, a administração política como campo de conhecimento, já que essa é a forma recorrente, como atestam E. Santos et al (2017), R. Santos et al (2017), R. Santos et al (2016), Amaral, Monteiro e Almeida (2015), R. Santos, Ribeiro e T. Santos (2009), entre outros. Esses autores defendem que a administração política se apresentaria como um campo de saber crítico e anti-gerencialista, pois partiria de uma denúncia da insuficiência técnica das estruturas de distribuição de riqueza no modo de produção capitalista (SANTOS, E., 2014). Assim, haveria no campo um potencial de emancipação tanto teórica, em relação à produção estrangeira (SANTOS, E., 2016) e local com vieses de estrangeirismo (SANTOS, E. et al, 2017), como prática, diante dos resultados sociais insuficientes do modo de produção capitalista (SANTOS, R., et al, 2016) e suas políticas públicas (SANTOS, R. et al, 2017).

Interessantemente, o campo da Administração Política é muitas vezes apresentado como que em disputa com a economia política (SANTOS, R., 2009a) tentando absorver os conhecimentos atribuídos à heterodoxia econômica (SANTOS, R., 2009b), ou ainda se aproximando da epistemologia (SANTOS, E., 2014). No entanto, esse conceito só passou a ser referido como um campo de saber a partir dos anos 2000. Algumas análises, como de Cristaldo, Ribeiro e Pessina (2017), Cunha (2016. 2019) e Queiroz (2015), sugerem implícita ou 
explicitamente que a administração política não represente um esforço de pesquisa crítica. Segundo esses autores, apesar das declarações de intenções emancipatórias presentes nos textos do campo, seus trabalhos recorreriam a procedimentos argumentativos e metodológicos que se distanciariam dessa finalidade.

Para elaborar esse estudo, partimos de uma revisão sistemática de literatura que, segundo Botelho, Cunha e Macedo (2011), é processo de prospecção de referências com o intuito de colher um rol de respostas para uma questão específica, que seja representativo do conceito em questão. Primeiro, foram realizadas pesquisas em três bases de produção científica - Scopus ${ }^{2}$, Web of Science ${ }^{3}$ e Google Scholar 4 - buscando retorno para o termo entre aspas "administração política" desde 1990 até 2019 no campos de título, resumo e palavras-chave (em português, inglês e espanhol). Segundo, como a Revista Brasileira de Administração Política até outubro de 2019 não fazia parte de nenhuma dessas bases, a mesma pesquisa foi repetida na busca do periódico em questão. Terceiro, o rol de artigos passou por uma análise rápida para descartar textos onde os termos "administração" e "política" não surgissem como um conceito único, chegando a um total de 83 artigos científicos publicados em oito diferentes periódicos nacionais, pertencentes a diferentes estratos na classificação Qualis da área de administração pública e de empresas da Coordenação de Aperfeiçoamento de Pessoal de Nível Superior (CAPES), desde A2 até B5.

A partir desse rol de textos, na quarta etapa cada um dos artigos foi lido e analisado individualmente para composição de uma base de dados que reunia informações de ano e periódico de publicação, palavras-chave, conceito de administração política, conceitos acessórios ao tema ${ }^{5}$, métodos de coleta e análise, tipo de trabalho (ensaio, artigo teórico, empírico

\footnotetext{
2 Disponível em: <https://www.scopus.com/home.uri>.

${ }^{3}$ Disponível em: <http://www.webofknowledge.com>.

4 Disponível em: <https://scholar.google.com/>.

${ }^{5}$ Foram encontrados aproximadamente 36 conceitos associadas ao tema da administração política, em menções realizadas no títulos e resumos dos artigos. Por meio do software NVivo então foram identificados os conceitos que mais apareciam, bem como os conceitos que as referências seminais mais associavam à administração política. Dessa forma, se chegou a lista de cinco conceitos: administradores, desenvolvimento, Estado, organização e gestão. Interessantemente, o conceito "empresa" apareceu em menos menções que "instituições". Ambos não aparecem nessa lista, pois
} 
qualitativo ou empírico quantitativo), referências, entre outras informações, a qual foi compilada no software de planilha eletrônica Microsoft Excel (MICROSOFT, 2016). O quinto procedimento consistiu em analisar o conjunto das referências da base por meio do software de análise bibliométrica VOSviewer (CWTS, 2020) para identificar os principais autores do campo e os trabalhos seminais, por meio tanto do fluxo como do número de citações das diferentes fontes 6 . Nessa quinta etapa se identificou que uma quantidade significativa de trabalhos faziam referência a um capítulo inédito do livro Administração Política como Campo de Conhecimento (SANTOS, 2009a) de França Filho (2009), bem como ao livro de R. Santos Keynes e a Proposta de Administração Política para o Capitalismo; ambos foram analisados e acrescentados na base ${ }^{7}$. Os trabalhos considerados seminais - aqui, entendemos como seminal aquele trabalho que recebeu mais citações nos trabalhos do campo - então foram revisados novamente, dessa vez de forma integrativa. Segundo Botelho, Cunha e Macedo (2011), a revisão integrativa, que pode ser quantitativa ou qualitativa, é um método de sumarização teórica de um conceito para uma análise aprofundada ${ }^{8}$. 0 objetivo dessa sexta etapa foi construir uma caracterização qualitativa que refletisse o campo da administração política, enfatizando (i) como os autores validam o campo, (ii) de que escopo de problemas e objetos se ocupam, (iii) quais os conceitos fundamentais, bem como (iv) premissas epistemológicas e ontológicas ${ }^{9}$.

foram mencionados comparativamente poucas vezes, bem como em quase nenhum dos trabalhos seminais apresentaram uma importância significativa.

6 Para encontrar as referências principais, foram descartados autores que não faziam parte do campo de conhecimento, mas muito referenciados, como Adam Smith, Karl Marx, John Maynard Keynes, Thomas Malthus etc. Assim, identificou-se que as citações recaem sobretudo sobre os trabalhos de R. Santos, Gomes, E. Santos e Ribeiro. E os trabalhos mais mencionados são R. Santos e Ribeiro (1993), R. Santos, Ribeiro e T. Santos (2009), R. Santos (2001. 2003. 2009a. 2009b. 2010a. 2010b), Gomes (2012. 2015), Ribeiro (2008), e E. Santos et al (2014).

7 Outros capítulos do livro Administração Política como Campo de Conhecimento (SANTOS, 2009a) foram amplamente citados pelos textos da base pesquisa. Mais especificamente, os capítulos 1 e 2 da parte 1 de autoria de R. Santos, bem como o capítulo 1 da parte 2, de Ribeiro. Porém, esses trabalhos já haviam sido publicados como artigos de periódicos científicos de circulação nacional antes da organização do livro e, por conta disso, já faziam parte da base de dados.

8 Os procedimentos bibliométricos e analíticos aqui mencionados foram base para um estudo mais amplo, sobre o conceito de administração política. Nesse artigo, portanto, se apresentam apenas uma parte dos resultados obtidos.

9 Entendemos epistemologia não como uma mera "teoria do conhecimento" (GRECCO, 2012, p. 16), mas como o estudo das formas consideradas legítimas de se produzir conhecimento cientificamente válido em um determinado campo de saber (JAPIASSÚ, 1979). 
Com essa perspectiva, então analisamos o campo de conhecimento da administração política a partir de quatro diferentes modelos interpretativos dos estudos organizacionais. 0 primeiro quadro referencial empregado foi o modelo dos paradigmas sociológicos nos estudos organizacionais de Burrell e Morgan (1979). Esse modelo nos permitiu analisar a produção em termos de suas adesões no que diz respeito ao posicionamento do campo nas dimensões da regulação social e da dicotomia procedimental entre o subjetivismo e o objetivismo. Em seguida recorreu-se ao esquema das metanarrativas dos estudos organizacionais de Reed (2012). Esse permite identificar quais os padrões recorrentes nas entrelinhas da estrutura discursiva de uma abordagem teórica, auxiliando a revelar a lógica mais geral por detrás da narrativa da administração política. Utilizamos ainda do círculo das matrizes epistêmicas proposto por Paula (2016). O diagrama auxiliou a mapear as raízes teleológicas, filosóficas e lógicas do campo em questão. Por fim, recorremos à matriz dos estudos críticos de gestão de Thomas Klikauer (2016), para mensurar o alcance da crítica possível a partir da administração política defendida nos trabalhos analisados.

A seguir, esse trabalho é dividido em três seções. Na primeira apresentam-se resumidamente, na forma de um referencial teórico, os modelos de análise. Na segunda seção há uma recuperação das características epistemológicas da administração política segundo apresentadas pelos autores do campo, já as cotejando a partir dos modelos. Na terceira seção reúne-se a análise propriamente dita, com comentários a título de discussão de resultados para, ao cabo, serem expostas breves considerações finais.

\section{À PROPÓSITO DOS ESTUDOS ORGANIZACIONAIS: QUATRO PERSPECTIVAS DE ANÁLISE}

Ambas, a administração e os estudos organizacionais - esses processos sociais que tanto se pretendem distintos (FRANÇA FILHO, 2009), mas tanto mais se mostram

O termo ontologia, por sua vez, faz mais sentido no contexto de uma fundamentação filosófica que assume, a priori, a existência de uma realidade em si, na qual o debate sobre a natureza dos fenômenos é capaz de se realizar de uma maneira não especulativa (DIETZ, 2006). Ao afirmar que aqui se abordará a ontologia da administração política, não pretendemos debater a existência concreta do fenômeno/processo/relação social chamado "administração política", mas sim quais as premissas de ordem ontológica das quais partem os trabalhos da proposta de administração política. 
sobrepostos dialogicamente (MATTOS, 2009) —, abordam sobretudo as problemáticas decorrentes da separação histórica entre as funções de direção e trabalho no âmbito da produção de valor (CUNHA, 2018). Nesse sentido, encontram-se na fronteira (poder-se-ia dizer, no "front de batalha") das disputas decorrentes das contradições estruturais que se perfazem no limiar da materialidade das sociedades contemporâneas. Talvez por isso tantas e tão distintas são as teorias e concepções da gestão e da organização, assim como, ou também quiçá por aquilo, são muitas as tentativas de sistematizar esses saberes.

Não obstante, podemos partir da premissa de que a administração política dialoga com a grande área dos estudos organizacionais - já que a partir daqui os consideramos em síntese com seu rival, a administração ${ }^{10}$ —, na medida em que se apropria da gestão como seu objeto, um processo social eminentemente organizacional. Dessa forma acreditamos que, uma vez imbuídos da tarefa de tecer uma análise da administração política, surge a dúvida acerca de qual seria seu lugar, sua contribuição à partir de, por assim dizer, os modelos interpretativos dos estudos organizacionais. Ou melhor, qual seria o espaço ocupado pela administração política no campo dos saberes dedicados às problemáticas da gestão e da organização? Diante da já mencionada pluralidade dos modelos interpretativos, essa tarefa se mostra, sem dúvida, vultuosa, nos obrigando a realizar primeiro uma argumentação inversa nos perguntando qual seria a contribuição dos modelos para a compreensão da administração política em si.

Dentre as muitas alternativas à disposição, construídas segundo matrizes de pensamento as mais diversas, destacam-se quatro conjuntos interpretativos: o modelo dos paradigmas sociológicos nos estudos organizacionais de Gibson Burrell e Garreth Morgan (1979), as metanarrativas dos estudos organizacionais de Michael Reed (2012), o círculo das matrizes epistêmicas de Ana Paula Paes de Paula (2016) e a matriz das quatro versões dos estudos críticos de gestão de Thomas Klikauer (2016). Cada um desses framework representam maneiras diferentes de enxergar os estudos organizacionais.

10 Em verdade, o mais indicado talvez fosse afirmar que a administração - o estudo e a prática da gestão em organizações privadas/públicas com a finalidade de atingir a eficiência - faz parte, está incluída nos estudos organizacionais (BURRELL; MORGAN, 1979. KLIKAUER, 2016. PAULA, 2016. REED, 2012). 
Qual seria sua contribuição de cada uma dessas matrizes para compreender a proposta de um novo campo dos estudos organizacionais? Acreditamos aqui que tais framework não são, necessariamente, excludentes entre si, mas talvez complementares talvez especificamente para a análise realizada nessa pesquisa. Essa pretensa complementaridade pode até não ser suportada pelo posicionamento dos próprios propositores. Por exemplo, Paula (2016) faz uma crítica contundente ao modelo de Burrell e Morgan, sugerindo que seu círculo das matrizes epistêmicas deve ser encarado como uma alternativa em substituição à aquele; da mesma forma, Klikauer (2016) deixa implícita uma crítica às abordagens pós-modernas, como a que parece inspirar o modelo das metanarrativas de Reed (2012). Nossa opinião é que cada um desses quadros analíticos tem o potencial de revelar aspectos diferentes de uma estrutura teórica e, portanto, permite lançar luz sobre elementos distintos do campo de conhecimento analisado aqui, a administração política. Assim, não queremos afirmar que os modelos podem ser sintetizados numa única estrutura, mas que sim no caso em questão, na análise da Administração Política, cada modelo é capaz de fornecer informações importantes a melhor compreensão do diálogo entre esse campo a grande área dos Estudos Organizacionais.

O modelo de Burrell e Morgan (1979) nos mostra mais claramente as aproximações de um campo de estudos organizacionais entre os espectros da regulação/mudança e da objetividade/subjetividade. Já o modelo de metanarrativas de Michael Reed (2012) nos permitem perceber quais os tipos lógica mais gerais de discurso, no que tange a explicação dos fenômenos gerencial e organizacional, que um campo vem a ser articular e reproduzir. 0 círculo das matrizes epistêmicas de Ana de Paula (2016) reforça a análise oferecendo uma maneira de expor claramente quais os fundamentos filosóficos, lógicos e teleológicos de um campo de saber, em termos do que chama de matriz epistêmica. E, Thomas Klikauer (2016), parte da abordagem crítica dos estudos organizacionais para entender qual a posição de uma proposta teórica no continuum entre os extremos da crítica radical e a contribuição funcional acrítica. Ou seja, cada modelo trabalha dimensões diferentes que não se excluem a priori: (i) adesão sociológica e posicionamento entre objetivismo e subjetivismo; (ii) lógica narrativa de discurso; (iii) adesões filosófico-epistemológicas; e (iv) contribuições críticas. 
Como já é bem difundido no métier dos estudos organizacionais, na classificação proposta por Gibson Burrell e Gareth Morgan (1979), os quatro paradigmas propostos — funcionalista, interpretativismo, estruturalismo radical e humanismo radical - se formam por meio do posicionamento no âmbito da escolha entre uma sociologia da regulação e a sociologia da mudança radical (eixo vertical), mais o posicionamento entre uma abordagem mais objetivista ou mais subjetivista (eixo horizontal). Assim sendo, é funcionalista um rol de saberes que adere à sociologia da regulação — ou seja, se propõem a realizar mudanças incrementais e se satisfazem com as condições estruturais das sociedades capitalistas -, partindo de uma abordagem objetivista (realista, positivista, determinista e nomotético). No extremo oposto, encontram-se os humanistas radicais, para os quais a inclinação teleológica é a ruptura estrutural das sociedades - sociologia da mudança radical -, seguindo uma orientação subjetivista (nominalista, anti-positivista, voluntarista e ideográfica). 0 campo do interpretativismo seria caracterizado por pertencer à sociologia da regulação, mas a partir de uma abordagem subjetivista. Por sua vez, o estruturalismo radical utilizaria de uma orientação objetivista, mas com fins de ruptura social (ver figura 1). 
Figura 1: Paradigmas sociológicos dos estudos organizacionais

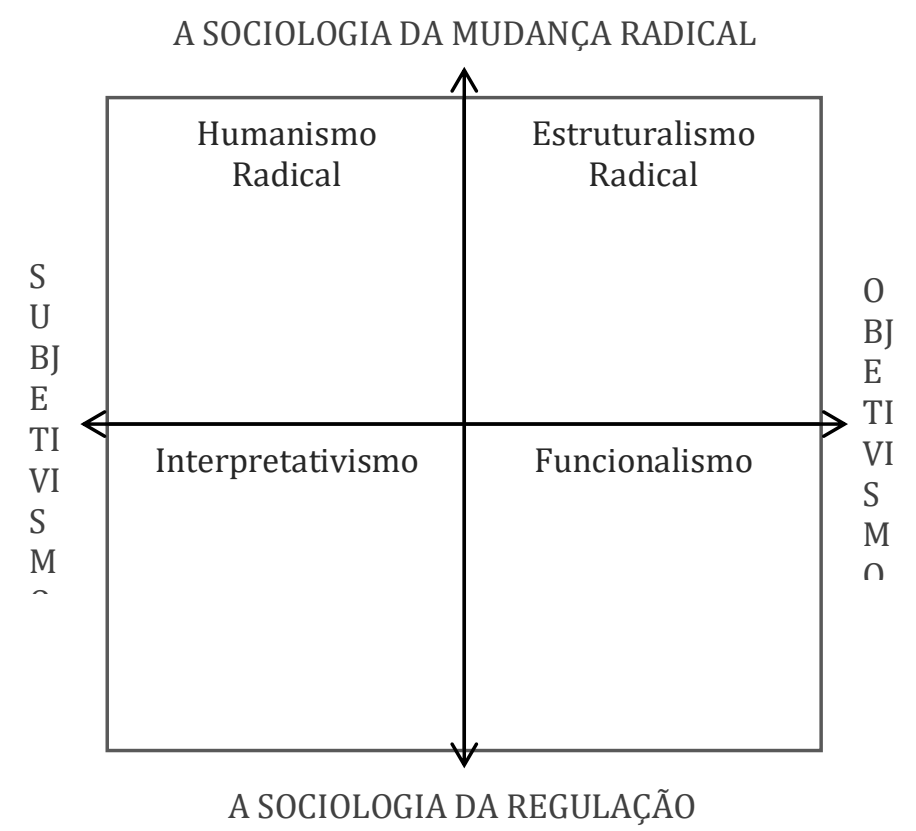

Fonte: traduzido de Burrell e Morgan (1979, p. 22)

Na proposta de Michael Reed (2012), os estudos organizacionais são classificados a partir de suas diferentes estruturas narrativas de explicação das realidades organizacionais. Para o autor, cada arcabouço teórico elabora um entendimento lógico sobre as possíveis causalidades e relações entre variáveis, visando estruturar a realidade de forma coerente e, assim, compondo uma narrativa que representa um rol de problemáticas, interpretações e soluções para as organizações. Essas exposições textuais seriam a manifestação do conjunto de premissas e aspirações dos autores a elas vinculadas, bem como de suas diferentes atitudes de conhecimento formando, segundo Reed (2012), seis diferentes metanarrativas: (1) racionalista; (2) integração; (3) mercado; (4) poder; (5) conhecimento e; (6) justiça.

Para o autor, a narrativa racionalista tem uma orientação positivista. Pesquisadores vinculados enxergariam a organização como uma ferramenta neutra, cujo funcionamento é regido pela técnica e por mecanismos racionais. A questão da ordem seria sua problemática principal. Por sua vez, na narrativa da integração a organização aparece como uma entidade 
viva, internamente harmônica e externamente adaptativa. Partem da metáfora organicista, que recorre a noções como evolução, complexidade e interdependência. Já a narrativa do mercado toma como premissa a ideia de que os processos das organizações são regidos e regulados externamente, pela lógica impessoal dos mercados. Nessa concepção, a organização assume um papel reativo, cuja existência é uma resposta natural/racional para os problemas do mercado (REED, 2012).

De acordo com o autor, pesquisadores vinculados à narrativa do poder afirmam que a “[...] organização [funciona] como uma arena de interesses e valores conflitantes, constituída pela luta pelo poder." (2012, p. 74). Seus processos internos são vistos como resultado de processos políticos, negociações, dominação, influência e hegemonia. $\mathrm{Na}$ narrativa do conhecimento a organização aparece como um fenômeno informacional. Partem da premissa de que o saber assume uma posição determinante na criação, aquisição e exercício do poder no século XX. Por isso, o controle dos processos de trabalho, assim como de formação e distribuição de conhecimentos, torna-se centrais. Por fim, na narrativa da justiça se resgatam a importância de discussões macrossociais nos estudos organizacionais, abordando temas como os problemas das instituições, distribuição de forças, o posicionamento histórico, estrutural e contextual de atores, bem como as questões da participação e da democracia. Nesse caso, o escopo de análise se desloca do micro para o macro. Para Michael Reed (2012), cada narrativa elege problemas e concepções distintas de organização, com conceitos também bastante próprios, bem como recorre a formas de representação da organização e palavras-chave que se mostram típicas (ver Quadro 1). 
Quadro 1 - Metanarrativas em Estudos Organizacionais

\begin{tabular}{|c|c|c|c|}
\hline $\begin{array}{l}\text { Metanarrativa } \\
\text { interpretativa }\end{array}$ & $\begin{array}{l}\text { Problemática } \\
\text { principal }\end{array}$ & $\begin{array}{l}\text { Representação } \\
\text { organização }\end{array}$ & Palavras-chave \\
\hline Racionalidade & Ordem & $\begin{array}{l}\text { Ferramenta Racional para } \\
\text { Alcance de Objetivos }\end{array}$ & $\begin{array}{l}\text { Positivismo; Eficiência; } \\
\text { Processo Decisório }\end{array}$ \\
\hline Integração & Consenso & $\begin{array}{lr}\text { Unidades } & \text { Sociais } \\
\text { Intermediárias e Orgânicas }\end{array}$ & $\begin{array}{l}\text { Bem-Estar; Relações } \\
\text { Harmonia; Evolução }\end{array}$ \\
\hline Mercado & Liberdade & $\begin{array}{ll}\text { Unidades de Alocação / } \\
\text { Mecanismos de Superação } \\
\text { de } & \text { Problemas } \\
\text { Transacionais } & \end{array}$ & $\begin{array}{llr}\text { Racionalidade } & \text { Limitada; } & \text { Mercado } \\
\text { Neutro e } & \text { Objetivo; } & \text { Evolução; } \\
\text { Adaptação } & & \end{array}$ \\
\hline Poder & Dominação & $\begin{array}{l}\text { Arena de Interesses } \mathrm{e} \\
\text { Valores em Conflito }\end{array}$ & $\begin{array}{l}\text { Política; Negociação; } \\
\text { Representação }\end{array}$ \\
\hline Conhecimento & Controle & $\begin{array}{l}\text { Fenômeno de Aglutinação } \\
\text { e Produção de } \\
\text { Conhecimentos }\end{array}$ & $\begin{array}{l}\text { Análise Micro; Relativismo; Pós- } \\
\text { Modernidade; Pós-Industrialismo }\end{array}$ \\
\hline Justiça & Participação & $\begin{array}{l}\text { Estrutura } \\
\text { Institucionalizada } \\
\text { Poder e Autoridade }\end{array}$ & $\begin{array}{l}\text { Estado, Indivíduo e Empresa; } \\
\text { Conflitos de Classe; Instituições; } \\
\text { Participação e Democracia }\end{array}$ \\
\hline
\end{tabular}

Fonte: adaptado de Reed (2012)

O Círculo das Matrizes Epistêmicas proposto por Ana Paula Paes de Paula (2016), por sua vez, nos auxilia a compreender os fundamentos epistemológicos de um campo de saber. Segundo a autora, cada uma das três matrizes epistêmicas por ela relacionadas se referem às premissas de construção de conhecimento, aos fundamentos (i) filosóficos, (ii) lógicos e (iii) teleológicos que um campo de saber pode vir a assumir. Paula (2016) destaca que existem o menos três matrizes epistêmicas: a empírico-analítica, a hermenêutica e a crítica. A matriz empírico-analítica se constitui a partir de uma filosofia positiva, com lógica formal e interesses de ordem técnica. A matriz hermenêutica, por sua vez, se fundamentaria na filosofia do significado e da representação (fenomenológica), por meio de uma lógica interpretativa, com interesses práticos. Por fim, a matriz crítica partiria de uma filosofia negativa (portanto, anti-positivista), fazendo uso da lógica dialética, para, assim, atingir interesses emancipatórios.

As diferentes "abordagens sociológicas" (PAULA, 2016, p. 26) produziriam saber e conhecimentos com base nessas matrizes fundamentais. Haveriam, assim, abordagens sociológicas puras, que fazem uso de uma, e apenas uma, dessas matrizes epistêmicas: funcionalismo (empírico-analítica), interpretativismo (hermenêutica) e humanismo radical 
(crítica). Mas também existiriam abordagens sociológicas híbridas, que combinariam duas ou mais matrizes epistêmicas: estruturalismo (empírico-analítica + hermenêutica), pósestruturalismo (hermenêutica + crítica), realismo crítico (empírico analítica + hermenêutica + crítica), entre outras (Figura 2).

Figura 2: Círculo das matrizes epistêmicas

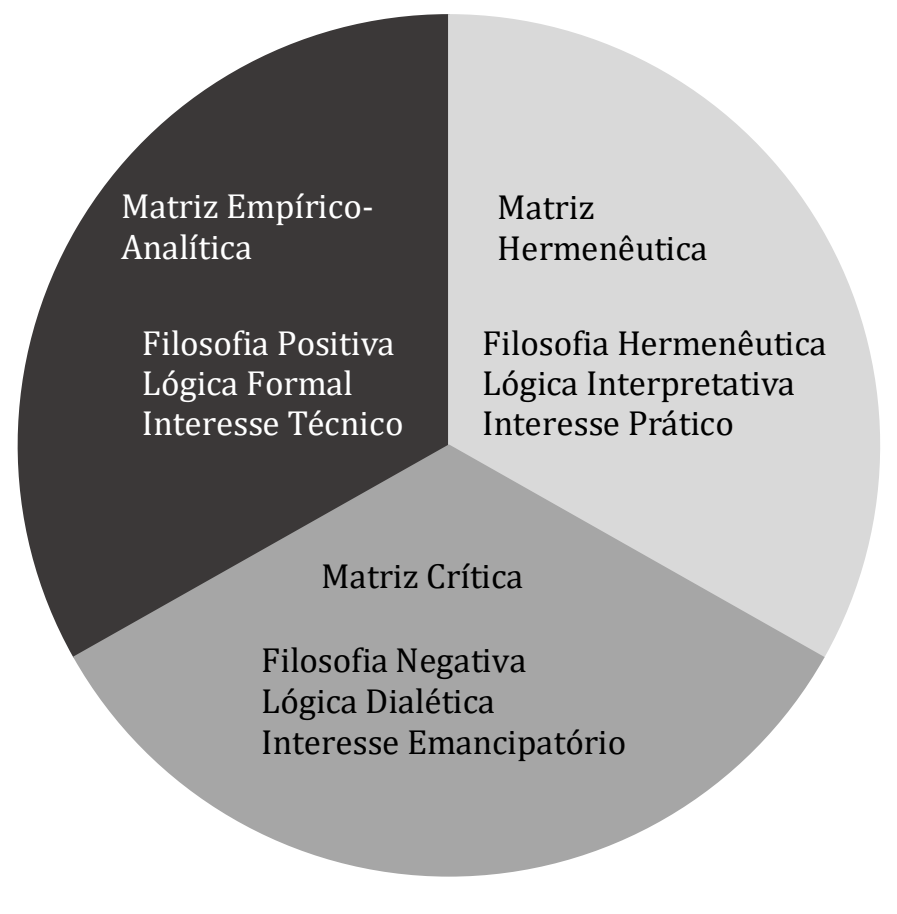

Fonte: Paula (2016, p. 36)

Por fim, Klikauer (2016) propõem uma matriz de classificação dos estudos organizacionais, com o intuito de verificar o potencial crítico de um conjunto de saberes vinculados ao campo. Sua matriz se constrói como um continuum entre dois extremos: de um lado (i) os estudos tradicionais de gestão, que segundo o autor contribuem para a dominação já que assumem abertamente um interesse técnico-empírico sobre a problemática do controle e, no outro extremo, (ii) a teoria marxista da gestão, que visa a libertação por meio de ruptura das estruturas sociais capitalistas, extinguindo assim a dominação, denotando um interesse crítico-emancipatório. Entre esses limites o autor posiciona dois quadrantes intermediários. Ainda dentro do espectro da dominação o autor localiza (iii) os estudos 
críticos de gestão que, segundo sua interpretação, não pretendem extinguir a dominação, mas atenuá-la: estes apresentariam um interesse hermenêutico no âmbito da compreensão e do entendimento, visando apenas reformar os aspectos marginalmente negativos do status quo. E, no lado da emancipação concreta, se encontraria (iv) a teoria crítica de gestão, para os quais a emancipação pode se dar no âmbito das intersubjetividades, com ênfase em questões simbólicas e da representação, como o gênero, a etnia, a cultura, entre outras.

A seguir, no Quadro 2, recuperamos em linhas gerais a matriz das contribuições dos estudos organizacionais para a crítica da gestão, conforme proposta por Thomas Klikauer (2016).

Quadro 2 - Matriz das contribuições dos estudos organizacionais para a crítica da gestão

\begin{tabular}{|c|c|c|c|}
\hline $\begin{array}{r}\text { Estudos Tradicionais de } \\
\text { Gestão }\end{array}$ & Estudos Críticos de Gestão & $\begin{array}{l}\text { Teoria Crítica da } \\
\text { Gestão }\end{array}$ & $\begin{array}{l}\text { Teoria Marxista da } \\
\text { Gestão }\end{array}$ \\
\hline $\begin{array}{r}\text { Taylor, Fayol, Ford, } \\
\text { Porter, etc. }\end{array}$ & $\begin{array}{r}\text { Alvesson, Willmott, Adler, } \\
\text { etc. }\end{array}$ & \multicolumn{2}{|c|}{$\begin{array}{l}\text { Adler, Ackroyd, Delbridge, Martin Parker, } \\
\text { Klikauer, etc. }\end{array}$} \\
\hline HBR, AMR, ASQ, etc. & BJM, JMS, OS, etc. & \multicolumn{2}{|c|}{ Capital \& Class, WES, Critical Sociology, etc. } \\
\hline $\begin{array}{l}\text { Interesse técnico- } \\
\text { empírico no controle }\end{array}$ & $\begin{array}{l}\text { Interesse hermenêutico na } \\
\text { compreensão/entendimento }\end{array}$ & \multicolumn{2}{|c|}{$\begin{array}{l}\text { Interesse crítico-emancipatório em } \\
\text { acabar/extinguir a dominação e buscar a } \\
\text { libertação }\end{array}$} \\
\hline
\end{tabular}

Fonte: traduzido e adaptado de Klikauer (2016, p. 5).

Acreditamos que esses quatro panoramas analíticos não são excludentes entre si, mas talvez, em uma última análise, complementares. Ao menos no que diz respeito à sua aplicação no caso em questão, que é o de analisar uma proposta de campo de conhecimento. Isso, muito embora esse potencial complementaridade pode não ser suportada pela fala dos próprios propositores. Por exemplo, Ana de Paula (2016) faz uma crítica contundente ao modelo de Burrell e Morgan, sugerindo que seu Círculo das Matrizes Epistêmicas deva ser encarado como uma alternativa em substituição a aquele. Em nossa opinião, cada um desses modelos esquemáticos contribui com informações e categorias diferentes que permitem lançar luz sobre aspectos distintos do campo de conhecimento aqui analisado. 
O modelo de Burrell e Morgan (1979) expõe mais claramente as aproximações de um campo de estudos entre os espectros da regulação/mudança e da objetividade/subjetividade. As metanarrativas de Michael Reed (2012) permitem perceber quais as lógicas mais gerais do discurso, no que tange a explicação dos fenômenos gerenciais e organizacionais, que um campo vem a ser articular e reproduzir. 0 círculo das matrizes epistêmicas de Ana Paula Paes de Paula (2016) reforça a análise oferecendo uma maneira de entender quais os fundamentos filosóficos, lógicos e teleológicos de um campo de saber. E, por fim, a matriz de Klikauer (2016) aponta o nível de aprofundamento emancipatório da crítica (ou sua ausência) realizada a partir de uma corrente dos estudos organizacionais. Crê-se aqui que, assim articulados, esses modelos permitem elaborar um melhor mapeamento das características da administração política enquanto campo de conhecimento que revele, afinal, se lugar no âmbito dos estudos organizacionais. Isso segundo as quatro dimensões que cada um dos modelos cobre: afinidade paradigmática; lógica narrativa; aderência epistemológica e; potencial emancipatório.

\section{A ADMINISTRAÇÃo POLÍTICA ENQUANTO CAMPO DE CONHECIMENTO}

Partimos da premissa de que a administração política como campo de conhecimento se insere nos estudos organizacionais, primeiro por referenciar e debater temas típicos da administração, segundo por conta de que faz referência a processos sociais relacionados às organizações, como a gestão, o Estado etc. A administração política é apresentada como um campo de conhecimento, segundo R. Santos, Ribeiro e T. Santos (2009), o qual se propõe avaliar e construir modelos de gestão do Estado (SANTOS, R. et al, 2017) com o intuito de contribuir para seu pretenso desiderato, o bem-estar da população (SANTOS, R.; GOMES, 2016). Os autores partem da premissa de que a consolidação de um campo de conhecimento depende da fixação de objeto e método próprios (SANTOS, E., 2014). O objeto da administração política seria, segundo R. Santos, Ribeiro e T. Santos (2009), a atividade de gestão, a qual seria analisada a partir do método analítico (GOMES, 2015).

É possível inferir que o momento de virada o qual levou R. Santos e outros autores a usar o termo "administração política" (2009a, p. 23) para um novo campo de conhecimento se 
deu em algum momento entre 2001 e 2003. Em 2001, R. Santos publicou um texto no qual ainda argumentava que a administração política era um objeto a ser estudado pela administração. Depois, esse mesmo artigo foi reproduzido com poucas alterações como capítulo de um livro organizado pelo autor em 2003 - obra que aqui analisamos na edição de 2009. Nesse texto, o autor afirma que,

[...] considerando que o objeto de estudo da administração é a gestão, então a preocupação fundamental no ensaio era saber qual fora o modelo de gestão que o País adotara para retomar o crescimento econômico, sobretudo saber como eram compreendidas pelo modelo as relações intergovernamentais e as relações entre o Estado e a sociedade. (SANTOS, R., 2009a, p. 26, grifos nossos).

Seu escopo de análise ali é o "modelo de gestão que o País adotara”, pretendendo ainda tratar das "as relações intergovernamentais" e entre o "Estado e a sociedade", usando a gestão para refletir sobre esses processos. Na sequência R. Santos afirma que “[...] a administração política é a concepção de um modelo de gestão das relações sociais que tem por objetivo garantir certo nível de bem-estar, expresso nas garantias plenas da materialidade." (2009, p. 37, nota n. 4, grifos nossos). Dessa citação é lícito assumir que o objetivo da administração política é propor - já que “concepção” remete a criação de algo novo - "modelos de gestão”. Segundo Klikauer (2013), a proposição de modelos de gestão visa o incremento de performance de organizações, sendo essa uma das características fundamentais do gerencialismo. ${ }^{11}$

11 Convém perceber a menção do conceito "modelo de gestão" realizada pelos autores do campo da Administração Política, cujo uso, no nosso entendimento, remonta à abordagem funcionalista. É possível inferir a partir do trabalho Burrell e Morgan (1979), que uma das principais características do funcionalismo no âmbito dos estudos organizacionais é objetivo propositivo. Autores funcionalistas partem da necessidade de sugerir a adoção de modelos de gestão, com o objetivo de aprimorar o funcionamento das organizações, sugerindo que suas estruturas não precisam de mudanças radicais, mas tão somente de reformas sobre como são usadas as forças produtivas. Ou seja, mudanças de gestão para atingir uma maior eficiência. Essa percepção é corroborada pela exposição de França Filho (2009), sobre o aspecto performático do gerencialismo em administração. 0 problema aqui está no fato de que mudar o escopo da categoria "empresa" para as "relações sociais" não significa, por si só, uma superação da adesão ao gerencialismo funcionalista. Isso porque o foco continua a ser a melhoria da performance da gestão sem engendrar uma crítica. 
No segundo capítulo daquele mesmo livro, R. Santos (2009b) traz um outro texto publicado previamente em periódicos científicos, uma revisão do institucionalismo, do gerencialismo e do regulacionismo - correntes heterodoxas da ciência econômica argumentando que seus conhecimentos deveriam fazer parte da administração. Nesse trabalho, o conceito de administração política foi também tratado como se se referisse a um fenômeno a ser estudado. Da mesma forma, o autor defende novamente que a administração política seria um dos objetos da administração. É digno de nota que o título do livro onde esses artigos foram publicados, organizado por R. Santos (2009), é Administração Política como Campo de Conhecimento, deixando a entender que se apresentariam as características desse novo campo. Porém, isso não acontece de fato. 0 único capítulo que se propôs como um debate epistemológico, de autoria de França Filho (2009), não trata especificamente da administração política, mas aborda os estudos organizacionais e a administração de um modo geral.

Um dos primeiros trabalhos que viria a apresentar a administração política como campo de conhecimento foi um artigo Bases Teórico-Metodológicas da Administração Política. Nesse texto, os autores afirmam que "[...] o que se atribui como não científico da economia, na verdade pertence a um novo campo do conhecimento, a administração política." (SANTOS, R.; RIBEIRO; SANTOS, T., 2009, p. 925, grifos nossos). Tanto um clamor de gênese - a administração política nascia ali como um campo de saber —, como um argumento de posse: o que a ciência econômica considerava proscrito, heterodoxo, deveria pertencer a aquele novo campo. Desse modo, a partir dali passou-se então a se referir à administração política como um pretendente a ramo original de ciência ligada a objetos gerenciais.

R. Santos, Ribeiro e T. Santos (2009) partem de uma reflexão acerca da natureza da administração, recorrendo a uma análise etimológica dos termos "administração" em português e "management" em inglês. Porém, o único artifício de referência que utilizam é a citação de um verbete de um dicionário da língua portuguesa, sem buscar outras fontes ou 
discussões já realizados pelos diversos autores do campo ${ }^{12}$. Desse expediente derivam a conclusão de que a atividade de administração se dividiria em duas dimensões, uma abstrata — política —, outra aplicada, a Administração Profissional. E daí afirmam que,

E o que cabe, então, à administração? Pura e simplesmente, a gestão. Assim, cabe à administração estruturar formas de gestão que viabilizem os objetivos da organização. Por essa razão, a gestão é apenas um dos conteúdos que dão forma institucional e essência às organizações. Então, podemos concluir que é a gestão e não a organização que caracteriza o objeto e que dá autonomia à administração enquanto um campo próprio do conhecimento. (SANTOS, R.; RIBEIRO; SANTOS, T., 2009, p. 930, grifos nossos).

Segundo os autores, a gestão seria o objeto que conferiria status de ciência à administração. Muito embora os autores argumentem acerca do porquê da organização não dever ser o objeto da administração, ${ }^{13}$ a gestão em si não é problematizada; não é nem apropriadamente discutida, muitos menos empírica, histórica ou teoricamente caracterizada. R. Santos (et al, 2017) retoma essa questão e argumenta que a concepção de gestão não foi adequadamente problematizada pelos autores do campo ${ }^{11}$. No entanto, mais uma vez o autor elabora esse argumento a partir de um rol restrito de referências. Por fim, R. Santos (et al, 2017) retoma o que foi dito por R. Santos, Ribeiro e T. Santos (2009) sem resolver as insuficiências deixadas por esse trabalho.

$12 \mathrm{O}$ debate sobre a natureza da administração e da gestão já foi realizado por diversos pesquisadores, a partir de diferentes matrizes epistemológicas. Cunha (2018) tece uma reflexão a partir da perspectiva marxista. Mintzberg (1973), por outro lado, aborda a problemática a partir de um estudo empírico com aproximações do funcionalismo. Mattos (2009) tece uma reflexão da natureza da administração a partir da filosofia, enquanto França Filho (2009) se vale dos estudos organizacionais como referência para discutir a administração, a gestão e as organizações. Alberto Guerreiro Ramos (1989) reflete sobre a gestão a partir de uma reflexão acerca das distintas formas de manifestação da racionalidade, seguindo uma adesão weberiana. Tragtenberg (2005) reflete sobre administração e ideologia, segundo uma perspectiva crítica que associa as perspectivas de Weber e de Marx. Isso entre muitas outras possíveis referências. R. Santos, Ribeiro e T. Santos (2009) e R. Santos (et al, 2017) escolhem ignorar esse debate ao apresentar suas definições de administração e gestão.

13 R. Santos, Ribeiro e T. Santos (2009) sugerem que a organização é meramente locus onde o fenômeno da gestão ocorre. No espaço organizacional se manifestariam outros fenômenos de outras naturezas, sendo a organização, portanto, também objeto de outras ciências. Assim, o objeto da administração, ou da administração política, não poderia ser a organização em si, mas tão somente o processo social que é peculiar à organização, a gestão. 
Percebe-se ainda uma tendência dos autores em entenderem que a realidade social e organizacional existe em si mesma, cabendo à administração política apenas desvelá-la. Nesse sentido, podemos dizer que suas premissas ontológicas caminham em direção ao que Burrell e Morgan entendem por realismo. 0 mesmo aparece no trabalho de Gomes de 2012, para quem a administração política se dedica à realidade macro das sociedades, pois '[...] é o ambiente "macroestrutural" que importa, porque é nele que se define o modelo de gestão que pode ter vários propósitos [...]' (GOMES, 2012, p. 16, grifos nossos). Da mesma forma, E. Santos afirma que "a administração procura examinar ou propor como os fatos devem ser." (2014, p. 194). Gomes ainda argumenta que “[...] a administração política se importaria em estudar as formas de gestão das relações sociais de produção no contexto de determinadas organizações sociais e econômicas, tanto no plano micro como, principalmente, no plano sistêmico." (2015, p. 16).

Uma das características notáveis é a percepção dos autores de que a gestão tem um princípio teleológico de fundo, um objetivo a priori: “por ser a gestão o objeto da administração, tem como propósito organizar as relações sociais de produção e distribuição para um melhor bem-estar da humanidade.” (SANTOS, R.; RIBEIRO; SANTOS, T., 2009, p. 931). Primeiro, parece haver ali um problema lógico, pois, ao partir da premissa "gestão é objeto da administração" não é possível derivar a conclusão "a gestão tem o propósito de organizar as relações sociais de produção e distribuição para atingir um melhor bem-estar da humanidade"14. Segundo essa é uma afirmação determinista, pois os autores parecem acreditar que indivíduos em posição de gestão só podem, ou só devem, agir em função do bemestar da coletividade. Para os autores, a ação dos indivíduos é determinada por esse fator externo. Essa tendência determinista também aparece no seguinte excerto:

[A] Administração Política, assume um relevante papel de ciência normativa e prescritiva, tendo em vista ser responsável por definir modos de comportamento, formas de relacionamento, padrões de gestão, modos de relações sociais de produção

14 Aparentemente, há nessa passagem uma falácia non sequitur, já que a premissa estabelecida não condiciona necessariamente a conclusão dos autores sobre o objetivo da gestão. Segundo Copi, Cohen e McMahon (2014, p. 123), non sequitur é uma retórica falaciosa na qual a conclusão simplesmente não se sustenta nas premissas, violando assim a coerência e concatenação textual da fala. 
e de distribuição, dentre outras modalidades de comportamento individual, organizacional e social que refletem, pois, o como organizar-se, o como preservar interesses e também o como construir bases para a transformação. (PINTO; RIBEIRO, 2014, p. 8, grifos nossos)

Ao defender que a administração política possui um papel normativo e prescritivo, essas autoras assumem que sua contribuição está em auxiliar na proposição de melhores formas de gestão. Não necessariamente da empresa, num sentido micro, mas da sociedade como um todo e de suas instituições em nível macrossocial, dentre elas o Estado. Porém, não como uma crítica estrutural, mas como uma sugestão de mudanças incrementais, já que a transformação mencionada não indica a superação das condições atuais das relações sociais de produção. Se trata de uma proposta reformista, com mudanças marginais, meramente distributivas ${ }^{15}$.

R. Santos, ainda defende que a administração política deve ser “[...] capaz de garantir a estabilidade nas relações sociais de produção, realização e distribuição" (SANTOS, R., 2008, p. 134, grifos do autor). Nessa passagem, não apenas assume como pressuposto a continuidade do modo de produção capitalista, como defende que a administração política deve contribuir para sua continuidade. A meta da administração política é a manutenção do status quo, mesmo que sugerindo reformas nos aparatos distributivos. Ainda nesse âmbito, E. Santos afirma que "[...] cabe à Administração Política definir como o sistema econômico deve ser gerido, qual o modelo de gestão que se adequa ao sistema econômico proposto pela economia política." (2014, p. 194, grifos nossos). 0 objetivo assumido aqui é claramente aprimorar a performance da gestão do Estado no modo de produção capitalista. Dessa forma, é lícito afirmar que a administração política se aproxima do que Burrell e Morgan (1979) chamam de uma sociologia da regulação.

15 Esse caráter reformista também foi percebido por Queiroz, quando afirma, sobre a administração política, que: "Reformar o capitalismo é o alvo e, como a própria condição histórica apresentou com o desmonte do Estado a partir do neoliberalismo da década de 90, [trata-se de] cometer o mesmo erro. [...] 0 objetivo da reforma é totalmente ilusório porque não possui caráter definitivo e sim transitório, podendo ser aceito ou não [...]. [É uma] reforma sem revolta. Mantendo a mesma estrutura social de dominação e exploração do homem sobre o homem, das classes capitalistas sobre as classes trabalhadoras." (QUEIROZ, 2015, p. 283). 
Além disso, há uma subordinação da administração política à economia política, atribuindo a esses campos funções diferentes e complementares, mas ainda subalternas e, dessa forma, integradas sistemicamente. Essa constatação fica mais evidente quando se analisa a opinião de Reginaldo Santos sobre a função do Estado: “[...] o seu papel [do Estado] é o de gestor e executor do projeto de nação, cuja finalidade é o bem-estar social. [...] O Estado é gestor porque tem a incumbência [...] de conceber as formas de gestão mais adequadas no processo de execução do projeto de nação que leve à finalidade do desenvolver social." (SANTOS, R., 2009a, p. 48).

Ao afirmar que o Estado tem por papel de gestar e executar o projeto de nação para o desenvolvimento, o autor sugere que essa instituição tem um objetivo a priori de promover o benefício coletivo. Nesse sentido, a administração política denuncia as dinâmicas que se desviam dessa ordem a priori. Essa constatação aparece nos trabalhos de R. Santos et al (2016) e R. Santos e Gomes (2016), como críticas do aspecto distributivo do Estado capitalista. Ou seja, os autores partem de um conceito de Estado a priori, com viés claramente normativo. Cunha (2016) reforça essa análise ao sugerir que na administração política subsiste um pressuposto da natureza do Estado como "[...] ente não contraditório, portador racional dos interesses comuns", o que, segundo o autor, torna necessário "explicar a si mesma ao revelar a [sua concepção acerca da] relação entre a gestão do estado e as contradições sociais, incluídas aí as classes sociais." (p. 282).

Os autores da administração política também assumem como premissa que, para se estabelecer como ciência, um campo precisa de um método próprio. Essa perspectiva aparece sobretudo nos trabalhos de Araújo (2012), Barreto (2012), Gomes (2012. 2014), E. Santos (2014), E. Santos et al (2016. 2017), R. Santos (2008) e R. Santos, Ribeiro e T. Santos (2009). É justo afirmar que se trata de uma influência direta filosofia da ciência de Thomas Kuhn, que é citado referenciado nesses trabalhos, a qual sugere que a evolução das ciências se dá pelo surgimento e consolidação de novos paradigmas, qualitativamente diferentes daqueles até então estabelecidos e, portanto, incomensuráveis entre si. Mas, se nos trabalhos aqui analisados o objeto dessa nova ciência - a administração política - sempre é a gestão, o 
método é mencionado um número limitado de oportunidades: mais especificamente, o método aparece três textos, os artigos de R. Santos, Ribeiro e T. Santos (2009), Gomes (2015) e E. Santos (2014).

R. Santos, Ribeiro e T. Santos (2009) tentam propor uma metodologia, quando afirmam que "[...] a nossa proposta metodológica para a administração política, aqui, é [...] da forma que segue: para qualquer nível de renda (PQNR), devemos adotar uma política de distribuição/bem-estar." (p. 933). Porém, os autores parecem confundir método de construção de conhecimento com um tipo de objetivo político - um princípio teleológico —, que aparece no texto se aproximando em verdade de um esboço de estratégia de ação para atingir uma finalidade prática. A base do argumento para essa colocação seria a premissa de que a ciência precisa contribuir para a melhoria das sociedades. Mas, sua interpretação dessa premissa se mostra uma aspiração funcionalista de tentar estabelecer de cima para baixo como a sociedade deveria ser. Trata-se de um "método" performático e normativo.

Ainda sobre método da administração política, Gomes afirma que,

No campo político, trata-se de um objeto de estudo bem delimitado, e a preocupação de Santos é concentrar-se e aplicar o método-analítico da administração política para compreender como se desenvolve a dinâmica da gestão das relações sociais de produção. Incluindo, obviamente, o Estado como ator imprescindível na condução dos destinos econômicos e da produção do sistema capitalista" (GOMES, 2015, p. 4, grifos nossos)

Considerando o rol de textos analisados para elaboração desse estudo, essa é a única menção ao método-analítico no âmbito da administração política. Porém, muito embora não seja dito abertamente, os autores do campo em muitos momentos realizam procedimentos que se aproximam do método-analítico. Isso acontece quando simplificam a atividade de distribuição de riqueza, concluindo que a resolução do problema distributivo apenas de vontade política (SANTOS, R., 2009a). Também se observa uma adesão ao método-analítico na base do argumento para solução da problemática do desenvolvimento, para o que bastaria apenas um pacto nacional (SANTOS, R.; GOMES, 2016). Da mesma forma, se revelam quando 
propõem a divisão entre instâncias macro e micro da administração (GOMES, 2012. 2014. SANTOS, E., 2014). Logo, é lícito assumir que, quanto à questão metodológica da administração política, se o que R. Santos, E. Ribeiro e T. Santos (2009) apresentam não é um método científico e sim um princípio teleológico, é em Gomes (2015) que se representa bem o método da administração política enquanto campo de conhecimento.

R. Santos, E. Ribeiro e T. Santos ainda defendem a existência de princípios ou leis gerais para a administração política. Segundo o trio de autores, essas "leis" são:

[1] só construir algo novo, depois de desfrutar plenamente do que já existe [...]. [2] para legitimar (integrar) o Projeto da Nação ou outro de qualquer organização/instituição torna-se necessário relativizar a hierarquia dos processos de construí-lo ou edificá-lo [...]. [3] em vista do resultado determinado, a forma de gestão mais adequada de qualquer projeto (do indivíduo, da organização ou da nação) está condicionada à compreensão da sua temporalidade. (SANTOS, R.; RIBEIRO, E.; SANTOS, T., 2009, p. 933-5).

A partir do que expõem Burrell e Morgan (1979), pode-se concluir que essa seria uma tendência nomotética. É digno de nota, porém, que tais "leis" são apresentadas pelos autores como aforismos performáticos, se distanciando do que se poderia esperar de leis científicas. Sua redação toma a forma de uma receita, de um caminho para o sucesso na gestão macrossocial, em muito semelhante aos manuais funcionalistas. Convém mencionar, porém, que em nenhum trabalho aqui analisado anterior a esse aparece qualquer intenção de encontrar leis gerais de funcionamento da realidade, exceto talvez em E. Santos (2014). Nem tampouco nos textos publicados a partir de 2009 se faz qualquer menção à essas "leis" propostas por R. Santos, E. Ribeiro e T. Santos (2009).

Será no trabalho de E. Santos (2014) que se retomará a discussão epistemológica da administração política. Esse autor reforça tanto a visão de que se trata de um campo de conhecimento, quanto a perspectiva de que seu objeto é a gestão e, mais especificamente, a gestão de processos macrossociais. Nesse sentido, converge com os trabalhos aqui analisados. Mas, é notável que esse autor tenha sido o primeiro do campo a realizar uma discussão epistemológica mais aprofundada. E. Santos (2014) toma como premissas a noção de campo 
de conhecimento em Pierre Bourdieu, do modelo dos paradigmas sociológicos de Burrell e Morgan, assim como a concepção da dinâmica entre paradigmas científicos de Thomas Kuhn. A partir disso, sugere que a administração política é um novo paradigma no campo dos estudos organizacionais; no entanto, o faz definindo-o como um campo bourdieusiano. Ao realizar esse expediente, num primeiro momento E. Santos (2014) indica a construção de uma epistemologia lógica a priori para o campo, pois delimita de modo especulativo, ex ante, qual o objetivo e o campo de trabalho em questão.

No entanto, no mesmo texto o autor defende que

[...] a Administração Política, enquanto campo, tem como finalidade maior desvendar, evidenciar, denunciar os propósitos e as contradições epistemológicos, metodológicos e praxiológicos das diferentes vertentes filosóficas da Administração. (SANTOS, E., 2014, p. 189, grifos nossos)

Nesse sentido, E. Santos propõe uma administração política que teria como objetivo principal estudar como se desenvolve a construção de saber num campo em particular, a administração, bem como desvelar como esse campo se insere socialmente em termos de práticas e métodos. Assim, o autor ensaia uma aproximação com uma epistemologia genética de inspiração piagetiana, ou talvez com uma epistemologia histórica do tipo bachelariana, como é possível inferir a partir da exposição de Japiassú (1979). Mas essa aproximação com epistemologias mais complexas não é aprofundada, pois na sequência o autor sugere que “[...] cabe à Administração Política definir como o sistema econômico deve ser gerido, qual o modelo de gestão que se adequa ao sistema econômico proposto pela economia política." (SANTOS, E., 2014, p. 194), assim reforçando uma visão normativa de ciência, com um objetivo performático e funcionalista.

É curioso notar que E. Santos faz afirmações com sentidos epistemológicos muito diferentes entre si. Isso pode ser verificado na seguinte colocação: “a Administração Política procura exercer o seu papel enquanto campo científico metaparadigmático, cuja finalidade se constitui em fazer a crítica das vertentes da Administração, especialmente no tocante à sua 
epistemologia, metodologia e prática social." (SANTOS, E., 2014, p. 196). E. Santos (2014) faz alusões a raízes epistemológicas cujos pressupostos são de difícil diálogo. 0 autor não deixa claro se esse expediente foi o resultado da escolha consciente de fazer com que o campo que transite entre diferentes matrizes epistêmicas, tentando assim formar uma abordagem sociológica híbrida ${ }^{16}$.

A última citação mencionada, a qual sugere que o campo da administração política seria metaparadigmático - o que, em Kuhn (1998), se refere ao estado de debate em um campo de ciência ainda imaturo, o qual não apresentaria paradigmas estabelecidos, como aliás o filósofo da ciência classifica a grande área das humanidades —, se dá num texto que, ao mesmo tempo, defende a administração política como um campo científico, e que seria necessariamente paradigmático segundo a exposição de Burrell e Morgan (1973). Pois bem, ou a administração política se apresenta como uma alternativa paradigmática no âmbito da administração, com objeto e método definidos num sentido kuhniano - e, assim, se impõe como um novo paradigma com o intuito de superar, absorver e substituir o anterior, pois incomensurável em relação a aquele —; ou se trata de um subcampo da epistemologia e da administração, dedicado a estudar as formas, limites, procedimentos e contribuições na produção de conhecimentos da ciência da administração. Acreditamos que essas duas opções são muito diferentes entre si, embora E. Santos as apresente de forma categórica como componentes da administração política, conforme foi exposto.

E. Santos ainda afirma que seu ensaio “[...] demonstrou que o conhecimento científico [...] fundamenta-se em princípios que prezam pela totalidade universal dos saberes, independentemente das suas categorias e especializações." (SANTOS, E., 2014, p. 196, grifos

16 No entanto, é preciso fazer justiça ao autor quanto ao aprofundamento da espistemologia, pelo menos no que tange à administração. Num outro texto, Elinaldo Santos, Reginaldo Santos e Vitor Braga (2014), realizam uma discussão recuperando referências epistemológicas para abordar a administração enquanto processo de produção de saber, chegando até mesmo a identificar a influência de algumas correntes filosófico-epistemológicas no campo, demonstrando que as bases primordiais da administração são a sociologia funcionalista e o positivismo. Porém, nos parece ainda mais estranho que tenha participado de uma discussão até mais aprofundada naquela oportunidade, mas simplesmente não tenha aproveitado aquele referencial para subsidiar melhor seu debate no âmbito da administração política no texto aqui analisado. 
nossos). Ora, ao dizer que o conhecimento científico atribuído a administração política "preza pela totalidade universal dos saberes", parece sugerir a existência de saberes universais, ou seja, válidos em qualquer contexto histórico e cultural. Assim, propõe que a administração política alcance um objetivo totalizante, universalista e, assim, se aproximam do reducionismo e do positivismo.

\section{E ENTÃO, EIS O CAMPO DA ADMINISTRAÇÃO POLÍTICA COMO PARTE DOS ESTUDOS ORGANIZACIONAIS}

Colocando em perspectiva o que foi até aqui exposto, é possível afirmar que a Administração Política, quando toma a forma de um campo de conhecimento, é ontologicamente realista, com viés determinista, se aproxima de uma epistemologia positivista e apresenta traços metodológicos de ordem nomotética. Em outras palavras, no eixo horizontal do modelo de Burrell e Morgan (1979), esse campo adere ao espectro objetivista. Além disso, os autores abraçam a inclinação teleológica de sugerir ações para reformar a gestão em âmbito macrossocial, produzindo sentenças e expressões prescritivas, declaradamente visando contribuir para o status quo da sociedade capitalista. Nesse sentido, levando em consideração o eixo vertical do modelo, a Administração Política integra a sociologia da regulação. Pode-se então dizer, com base nas informações e textos que foram aqui cotejados, que a administração política, quando se apresenta como um campo de conhecimento, estaria situada no quadrante inferior direito do modelo, portanto compondo o campo funcionalista dos estudos organizacionais. No Quadro 3 a seguir, fazemos um resumo das características da administração política aqui elencadas. 
Quadro 3 - Características da administração política enquanto campo de conhecimento segundo o modelo de Burrell e Morgan, um campo funcionalista

\begin{tabular}{|c|c|}
\hline Premissas & Características da administração política \\
\hline Premissa ontológica & Realismo \\
\hline Premissa quanto a natureza da ação humana & Determinista \\
\hline Premissa epistemológicas & $\begin{array}{l}\text { Positivismo (reducionismo, método- } \\
\text { analítico) }\end{array}$ \\
\hline Premissa metodológicas & Nomotético \\
\hline Eixo horizontal: & Objetivismo \\
\hline Objetivos gerais & Prescritivos para manutenção do status quo \\
\hline Direcionamento crítico & Contra fatores que comprometem a ordem \\
\hline Natureza da interações sociais & Consensuais \\
\hline Ênfases & Integração e Solidariedade \\
\hline Função dos sistemas sociais & Satisfação das necessidades coletivas \\
\hline Eixo vertical: & Sociologia da regulação \\
\hline
\end{tabular}

Fonte: elaboração própria a partir da bibliografia consultada, 2019.

Algumas ressalvas, porém, são necessárias. Primeiro, no que diz respeito à constatação de aproximação com o positivismo da administração política, só foi possível encontrar duas das quatro características citadas: o reducionismo e o método-analítico. Ainda assim, esse último numa única citação. Além disso, é preciso notar que em vários momentos os autores do campo aqui estudados enfatizam a necessidade de mudanças sociais, embora nenhum deles engaje seriamente em proposições de mudanças estruturais. 0 foco de seus trabalhos está em sugerir os processos sociais capitalistas poderiam trabalhar melhor pela plena realização de suas potencialidades. Tanto essa ênfase na mudança, como o positivismo apenas parcialmente representado, em nossa opinião, relativiza a adesão da administração ao funcionalismo. Porém, dado o peso das outras características, talvez permita dizer que o campo da administração política seja um tipo de funcionalismo atenuado.

No contexto das metanarrativas propostas por Reed (2012), o discurso da administração política pode ser identificado com a narrativa da justiça. Isso fica evidente quando os autores centrais do campo demonstram uma preocupação com aspectos macrossociais, como a gestão das relações sociais, do Estado, do desenvolvimento etc. Além disso, o posicionamento dos autores em busca de parâmetros mais justos de distribuição de riqueza - sua "metodologia" PQNR —, também reforça essa adesão, visto que caracteriza uma preocupação com questão da participação ampla das pessoas na divisão das riquezas 
sociais no modo de produção capitalista. De certa forma, podemos argumentar que isso caracterizaria a administração política como aderente a uma ideologia coletivista.

Também é lícito mencionar como as palavras-chave da narrativa da justiça se encontram entranhadas no discurso da Administração Política. São várias vezes mencionadas categorias como o Estado, o governo, às relações sociais de produção e distribuição, entre outras. Inclusive Santos (2009b) reivindica para o campo aqueles saberes que são desprezados pela ciência econômica mainstream: institucionalismo, gerencialismo e regulacionismo. Não por acaso, essas três correntes de pensamento se dedicam à aspectos macrossociais, como o papel das instituições nas escolhas de atores sociais (HODGSON, 2001), o peso político e social das grandes corporações capitalistas (KORTEN, 2015) e dos gestores (GALBRAITH, 1988), assim como a interação entre o Estado, representantes da Empresa e representações trabalhistas para compor uma via de desenvolvimento regulada (BOYER, 2015).

Não foi encontrada uma concepção de organização no campo da administração política. Como, em grande parte, o escopo desse campo transita entre questões macrossociais (SANTOS, R., 2001, 2009a) e discussões epistemológicas (SANTOS, R.; RIBEIRO; SANTOS, T., 2009, SANTOS, E., 2014), nos trabalhos analisados não se observou uma ideia original, ou sequer claramente discernível de organização, que seja característica. 0 tema surge indiretamente na discussão do conceito de "administração profissional", como quando afirmam que,

[...] está associada à dimensão da produção/organização da materialidade que vai levar à finalidade da sociedade. [...] responsável [...] por todas as etapas operativas do projeto da nação. Assim, a administração profissional compreende todos aqueles profissionais que, direta ou indiretamente, estão responsáveis pela execução do projeto da nação [...]. (SANTOS, R., 2009b, p. 49)

Ou no contexto em que tratam do objeto da administração enquanto ciência, quando a organização é mencionada para que seja logo em seguida descartada: 
[...] as organizações/instituições, como expressões das relações sociais, constituem objetos de estudos de diferentes campos do conhecimento. [...] Embora as organizações/instituições sejam o gênero que contém elementos essenciais do objeto da disciplina administração, elas são espaços particulares, onde apenas habita o objeto. A essência perpassa o espectro das relações sociais internas das organizações e se estabelece nos limites das relações sociais mais amplas; portanto, no âmbito da sociedade. Essa diferenciação é fundamental, pois nos permite entender por que as organizações não são o objeto da ciência da administração. [...] Então, podemos concluir que é a gestão e não a organização que caracteriza o objeto e que dá autonomia à administração enquanto um campo próprio do conhecimento. (SANTOS, R.; RIBEIRO; SANTOS, T., 2009, p. 930-1).

Convém destacar que a noção de organização aparece confundida com a de instituições — ambas sendo definidas categoricamente como "expressões das relações sociais" - como se se tratassem da mesma qualidade de processos sociais, estudadas apenas a partir de diferentes nomenclaturas. Porém, essa caracterização não é detalhada pelos autores, nem muito menos são mencionadas referências para sustentar essa afirmação. Assim sendo, reafirmamos, a Administração Política, no modelo de Reed (2012), se vincula à metanarrativa da justiça, como resumimos no Quadro 4 a seguir.

Quadro 4 - A metanarrativa da administração política enquanto campo de conhecimento

\begin{tabular}{|c|c|c|c|c|c|}
\hline & $\begin{array}{l}\text { Problemática } \\
\text { central }\end{array}$ & $\begin{array}{l}\text { Palavras } \\
\text {-chave }\end{array}$ & Posicionamento nos debates & Organização & Metanarrativa \\
\hline \multirow[t]{4}{*}{$\begin{array}{l}\text { Administraçã } \\
\text { o Política }\end{array}$} & \multirow[t]{4}{*}{$\begin{array}{l}\text { Distribuição } \\
\text { (Participação) }\end{array}$} & Estado & $\begin{array}{l}\text { Lógica de } \\
\text { Explanação: }\end{array}$ & \multirow{4}{*}{$\begin{array}{l}\text { Expressões } \\
\text { das relações } \\
\text { sociais }\end{array}$} & \multirow[t]{4}{*}{ Justiça } \\
\hline & & Gestão & $\begin{array}{l}\text { Adesão } \\
\text { Epistemológica } \\
:\end{array}$ & & \\
\hline & & \multirow[t]{2}{*}{$\begin{array}{l}\text { Relações } \\
\text { Sociais }\end{array}$} & $\begin{array}{ll}\text { Nível de } & \text { Global } \\
\text { análise: } & \end{array}$ & & \\
\hline & & & Coletivismo & & \\
\hline
\end{tabular}

Fonte: elaboração própria a partir da bibliografia consultada, 2019.

Se observada a partir da perspectiva do círculo das matrizes epistêmicas de Paula (2016), encontramos mais algumas pistas para melhor compreender o lugar do campo de conhecimento da administração política dos estudos organizacionais. Seguindo o que foi exposto na seção anterior, é lícito afirmar que a raiz filosófica desse campo tem uma forte inspiração positivista. É um campo que demonstra buscar leis gerais para explicar os processos sociais (universalista), com vistas a analisar uma realidade percebida de modo objetivo (realista), isso por meio do método analítico (reducionista). 
A constituição lógica de seus argumentos em nenhum momento recorre à contradição ou a dialética. Nem tampouco se utilizam de uma análise das representações simbólicas coletivamente compartilhadas, nem muito menos se referem às interpretações dos atores sociais envolvidos num dado contexto fenomênico. Os textos de R. Santos, E. Ribeiro e T. Santos (2009) e R. Santos (2001, 2009a, 2009b, 2010a, 2010b) são escritos segundo um raciocínio explicitamente dedutivo, a priori. Se, conforme foi exposto, incorrem em incongruências lógicas, isso parece ser muito mais decorrente de falhas argumentativas pontuais do que algo motivado por algum desejo de rompimento com a lógica formal. Do mesmo jeito, Gomes (2012, 2014) e E. Santos (2014), tampouco recorrem à dialética ou a interpretação simbólica, sua realidade é objetiva e sua lógica de construção se apresenta como eminentemente formal.

No que diz respeito a questão teleológica, percebemos, porém, uma dupla característica. A primeira aparece em vários textos, nos quais R. Santos (2001, 2009a, 2009b, 2010a, 2010b), Gomes (2012. 2015), E. Santos (2016), E. Santos et al $(2014,2017)$ e, sobretudo, R. Santos e Gomes (2016), afirmam que é preciso que as sociedades passem por mudanças. Sua principal preocupação é a de atenuar os efeitos negativos do capitalismo, embora em grande parte essa preocupação permaneça circunscrita ao aspecto distributivo, além de parecerem incapazes em (ou não inclinados a) perceber a influência das estruturas de produção no aspecto distributivo do modo produção dominante. Ou, dito de outra forma, teleologicamente buscam até um certo tipo de emancipação, eminentemente material e timidamente escondida em sua preocupação com os conceitos retoricamente apelativos de desenvolvimento e distribuição. Nesse sentido, pode-se dizer que apresentam um tênue interesse emancipatório, de caráter reformista na margem.

Porém, a ênfase dos autores está no como fazer, o que é constantemente reforçado em muitos trabalhos - como R. Santos (2009a, p. 44), Gomes (2012, p. 11), R. Santos, E. Ribeiro e T. Santos (2009, p. 935) ou R. Santos et al (2016, p. 1031), entre outros - , assumindo que o atingimento daquele objetivo é tão somente uma questão de mudança no sentido escolhas de gestão a partir das relações sociais, ou do Estado. Assim, sugerem que é preciso aprimorar de 
maneira incremental a gestão; como se a gestão, em si, não fosse reflexo e extensão das relações de poder e interesses de uma sociedade, mas tão somente um dado técnico subordinado exclusivamente à uma razão percebida de forma idealista. Nesse sentido, a administração política enquanto campo preserva o interesse de constituir uma técnica melhor, mais bem adequada, para resolver um problema.

Quadro 5 - A administração política enquanto campo de conhecimento a partir do círculo das matrizes epistêmicas de Ana de Paula

\begin{tabular}{|c|c|c|c|}
\hline Fundamentos & Adm. Política & Matriz Aderente & Abordagem Sociológica \\
\hline Filosofia & Positiva & \multirow{3}{*}{$\begin{array}{l}\text { Matriz Empírico- } \\
\text { Analítica }\end{array}$} & \multirow{4}{*}{$\begin{array}{l}\text { Híbrida (Empírico-Analítica + } \\
\text { Crítica), com preponderância da } \\
\text { Matriz Empírico-Analítica }\end{array}$} \\
\hline Lógica & Formal & & \\
\hline \multirow[t]{2}{*}{ Interesses } & Técnico & & \\
\hline & Emancipatório & Matriz Crítica & \\
\hline
\end{tabular}

Fonte: elaboração própria a partir da bibliografia consultada, 2019.

No Quadro 5, então, resumimos a nossa análise da administração política enquanto campo a partir do círculo das matrizes epistêmicas de Paula (2016). Seu fundamento na filosofia positiva, com uma lógica formal e o interesse técnico, remete à matriz empíricoanalítica. Porém, a constante reafirmação de uma necessidade de emancipação material, ainda que circunscrita ao problema distributivo, denota também uma aproximação de interesse emancipatório, típico da Matriz Crítica. Portanto, podemos dizer que a administração política é uma abordagem sociológica híbrida, pois associa duas matrizes, a empírico-analítica e a crítica, com clara predominância da primeira.

Por fim, mas não menos importante, analisamos como a administração política pode se situar no quadro proposto por Thomas Klikauer (2016). Conforme foi exposto anteriormente, as aspirações críticas da administração política se limitam aos aspectos distributivos do modo de produção capitalista, com um objetivo reformista (Queiroz, 2015). Isso fica bastante evidente na "metodologia" proposta, de que a distribuição de riqueza seja distribuída "para qualquer nível de renda" (PQNR). Esse problema distributivo aparece na crítica da administração política como uma questão meramente técnica, como se fosse algo que dependesse exclusivamente da vontade política dos gestores do Estado. 
Ainda assim, a proposta da administração política pretende apenas atenuar os efeitos típicos da dominação no modo de produção capitalista, sem alterar as condições estruturais de seu funcionamento. Nesse sentido, é apenas micro-emancipatório, buscando uma gestão que seja justa no âmbito da distribuição de renda. Dessa forma, acreditamos que interesse principal do campo se aproxima dos estudos críticos de gestão - "Critical Management Studies (CMS)" (KLIKAUER, 2016, p. 2) — que, segundo Klikauer, apresentam uma orientação estritamente hermenêutica, vinculado ao significado de conceitos. Porém ao não mencionarem os aspectos da dominação intra-organizacional, ou seja, ao não contemplar a gestão ética de organizações, elaboram uma reflexão ainda menos contundente que os CMS. 0 sentido da crítica na administração política se distancia da teoria crítica frankfurtiana, pois não se compromete com uma ruptura metodológica com o saber funcionalista dos estudos tradicionais em gestão - "Traditional Management Studies (TMS)" (KLIKAUER, 2016. p. 3). Da mesma forma, se distancia do marxismo, na medida em que não se posiciona de forma antagônica às relações de produção e apresamento de mais-valor tipicamente capitalistas; pelo contrário, se pretende funcional ao modo de produção dominante, já que visa corrigir seus erros para garantir sua continuidade e bom funcionamento.

No Quadro 6 a seguir, propomos então uma síntese de como percebemos a inserção da administração política nos estudos organizacionais: sua orientação é funcionalista, com tênue adesão à metanarrativa da justiça, a partir de uma abordagem sociológica híbrida — matriz empírico-analítica e matriz crítica, porém reformista. 
Quadro 6 - Integração da administração política aos estudos organizacionais, segundo os modelos de Burrell e Morgan (1979), Reed (2012), Paes de Paula (2016) e Klikauer (2016)

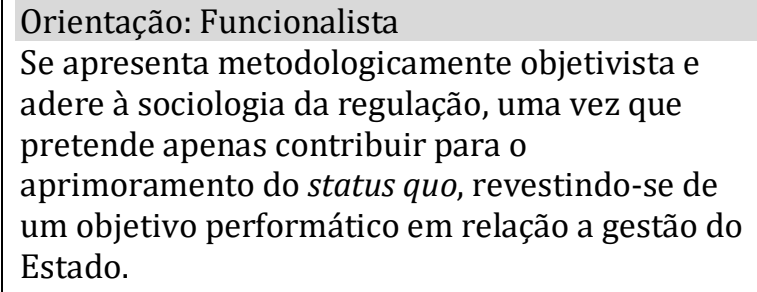

\section{Metanarrativa: Justiça}

Apresenta uma estrutura discursiva que remete à macro fenômenos como o Estado e o desenvolvimento, enfatizando a problemática da distribuição de renda.

Fonte: elaboração própria a partir da bibliografia consultada, 2019.

A opinião que se forma ao cabo dessa análise é a de que a administração política como campo de conhecimento apresenta em duas inconsistências mais sérias. A primeira refere-se ao fato de que, ao contrário das expectativas de E. Santos (2014), Gomes (2012, 2014), Barreto (2012), entre outros, a produção aqui analisada não demonstra se tratar de um campo de pesquisa crítica; o alcance de sua crítica é a reforma do Estado. Como exposto anteriormente, os indícios são de que o campo se aproxima do funcionalismo. Sua adesão à narrativa da justiça, bem como certa inclinação com um interesse que pode ser considerado emancipatório, atenuam isso, mas não é o suficiente para sugerir um rompimento com o funcionalismo, o que aparece mais claramente no modelo de Klikauer (2016).

Posições como a de R. Santos (2008) deixam a entender que o modo de produção dominante não deve ser contestado, apenas reformado, e mesmo isso sem afrontar os princípios e expectativas da classe dominante. R. Santos, Ribeiro e T. Santos (2009), Araújo (2012) e mesmo E. Santos (2014) e R. Santos et al (2017), ainda deixam a entender que a administração política se contentará com o papel de manter a estabilidade funcional das sociedades contemporâneas, ou seja, sugerem uma integração sem conflitos. 
A segunda é a de que esse esforço de transformação da administração política em um campo de conhecimento parece sofrer com alguns dilemas epistemológicos a serem clarificados. Uma das principais características dos autores da administração política, seja de R. Santos (2007. 2008), R. Santos, Ribeiro e T. Santos (2009), Gomes (2012. 2014), R. Santos et al (2017) e E. Santos (2014), é tentar fazer uma discussão epistemológica da administração sem proporcionar evidências de um estudo aprofundado e bem mapeado da própria epistemologia. Os primeiros fazem a discussão com base em definições especulativas, de senso comum e com certa superficialidade argumentativa. Já E. Santos (2014), quem mais se esforça no sentido de uma reflexão epistemológica profunda, se basta das noções de campo em Pierre Bourdieu, de paradigmas científicos de Thomas Kuhn e do modelo dos paradigmas sociológicos nos estudos organizacionais de Burrell e Morgan. Nesse último caso, o autor não enfrenta a problemática de que os pressupostos epistemológicos dessas referências apresentam um diálogo complexo, colocando em risco a possibilidade de servirem como fundamento para o erguimento de um novo campo de conhecimento. Isto, pois, aqueles autores partem de premissas de conhecimento em muitos aspectos distintas, assim como de concepções ontológicas cujo diálogo é problemático.

R. Santos et al (2017) se propõem a fazer, novamente, esse debate epistemológico, mas ao fim parte da premissa de que essas questões aqui mencionadas teriam sido resolvidas nos trabalhos anteriormente mencionados, o que não é evidente segundo a análise realizada para esse estudo. Em suma, para realizar seus próprios objetivos a administração política carece de um aprofundamento no estudo da epistemologia, de quais são as opções e correntes à disposição; assim como os autores precisam clarificar quais são suas intenções, se um campo, se estudos críticos, ou se 'fiel epistemológico' da administração.

\section{CONSIDERAÇÕES FINAIS}

A perspectiva desse artigo foi a de realizar uma reflexão acerca da administração política enquanto campo de conhecimento. Como objetivo principal, procurou-se refletir sobre o lugar da administração política na grande área dos estudos organizacionais. Para tanto, foi realizada uma revisão sistemática e integrativa de literatura. A seguir, foram 
empregados quatro diferentes modelos de análise dos estudos organizacionais para caracterizar a administração política: o modelo dos paradigmas sociológicos nos estudos organizacionais de Burrell e Morgan (1979), o modelo das metanarrativas apresentado por Michael Reed (2012), o círculo das matrizes epistêmicas de Ana Paula Paes de Paula (2016) e a matriz dos estudos críticos de gestão de Thomas Klikauer (2016).

A primeira seção foi dedicada à recuperação em linhas gerais dos modelos mencionados. A partir de (i) Burrell e Morgan (1979), expusemos de forma resumida as características dos paradigmas funcionalista, interpretativista, estruturalismo radical e humanismo radical. Já por meio do trabalho de Reed (2012), visitamos em linhas gerais as metanarrativas da razão, integração, mercado, poder, conhecimento e justiça. Da exposição de Paula (2016) obtivemos sua argumentação acerca das matrizes epistêmicas empíricoanalítica, hermenêutica e crítica, bem como as noções de abordagens sociológicas puras (que se pautam em apenas uma matriz) e híbridas (que combinam matrizes diferentes). Por fim, recorrendo à Klikauer (2016), apresentamos sua matriz de contribuição para a crítica da gestão.

Na segunda seção realizou-se uma revisão de literatura sobre administração política enquanto campo de conhecimento. Ali, relacionaram-se evidências para sustentar que, enquanto campo, a produção analisada demonstrou possuir característica tipicamente: realistas, deterministas, positivistas e nomotéticas. Além disso, percebemos também indícios de uma tendência prescritiva, que aparenta enfatizar aspectos de harmonia, estabilidade de continuidade das realidades organizacionais e sociais. Em outros termos, suas principais aspirações seriam de ordem reformista incremental, com tendência à apenas corrigir falhas nos resultados distributivos dos sistemas de gestão capitalista do Estado. Ainda nessa seção argumentou-se que a administração política procura enfrentar sobretudo questões macrossociais, a partir de uma problemática ligada às questões da participação (distribuição), visando articular aspectos micro organizacionais a partir do conceito de "administração profissional”, com aspectos macro, a gestão das relações sociais. Além de mencionar novamente que o campo se pauta por premissas filosóficas positivistas, também foi 
identificado que sua matriz de construção lógica é formal, assim como articulam interesses emancipatórios e técnicos.

Na terceira seção, então, sugeriu-se que a administração política, no modelo de Burrell e Morgan (1979), se aproxima de uma abordagem objetivista, considerando o eixo horizontal do modelo. Além disso, de acordo com as características observadas, a administração política estaria mais próxima da sociologia da regulação, na parte inferior do modelo de Burrell e Morgan a partir do eixo vertical. Assim sendo, conclui-se que, a partir dos trabalhos aqui analisados, o campo da Administração Política apresenta características do funcionalismo. Ainda nessa seção, argumentou-se que o campo em questão se vincula a narrativa da justiça no modelo de Reed (2012), a partir de um discurso de orientação totalizante que enfatiza lacunas (ainda que marginais) nos processos distributivos do modo de produção capitalista.

Com base no modelo de Paes de Paula (2016), afirmou-se que a administração política se apresenta como uma abordagem sociológica híbrida, que articula características da matriz empírico-analítica (filosofia positivista, lógica formal e interesse técnico) e da matriz crítica (interesse emancipatório). Nesse caso, a matriz empírico-analítica aparece como dominante, enquanto que o interesse emancipatório exerce um papel menor no pensamento da administração política. E, por fim, no modelo de Klikauer (2016) pudemos identificar a administração política como um estudo crítico de gestão com pretensões meramente reformistas, portanto se orientando para assegurar a estabilidade do modo de produção capitalista por meio da correção de resultados indesejados.

É interessante notar que, embora a administração política seja apresentada como (i) um campo de conhecimento de (ii) potencial crítico, os propositores deixam a desejar em ambos os intentos. A definição do objeto e método - procedimento assumido pelos próprios autores como forma de validação de um campo científico - esbarra numa exposição incipiente sobre o conceito de gestão, bem como numa argumentação ainda embrionária acerca do método. Os esforços de validação epistemológica do pretenso nosso campo de conhecimento realizados se mostram insuficientes ou inconclusos. E a possibilidade de formação de um estudo crítico estaciona numa formula a priori - o método PQNR - que não 
enfrenta com profundidade as causalidades e determinantes do aspecto distributivo no capitalismo.

Nesse sentido, já encaminhando possíveis desdobramentos a partir dessa reflexão, acreditamos que há um potencial de desenvolvimento na perspectiva de análise de aspectos macrossociais a partir das categorias da gestão. A riqueza do movimento da administração política se encontra principalmente nessa perspectiva de analisar os aspectos macroestruturantes da gestão no plano das relações sociais. Porém, a nosso ver, para se firmar como campo se faz necessário um esforço epistêmico de maior envergadura que venha a suprimir as insuficiências observadas, quais sejam (i) uma exposição mais aprofundada de objeto e método, bem como (ii) uma indicação mais clara do papel que pretendem ocupar no bojo dos estudos organizacionais - e fazer as adaptações necessárias na narrativa, uma vez que a pretensão de formar um estudo crítico esbarra na adesão ao funcionalismo e a matriz epistêmica empírico-analítica. Também, a nosso ver, se faz necessário um esforço no sentido de apreciar com mais clareza e concretude a existência desse fenômeno/processo/relação social, a administração política, tal como aparece descrito em R. Santos e Ribeiro (1993) e R. Santos (2001. 2003), por meio de validação empírica, histórica ou até mesmo ideográfica.

\section{REFERÊNCIAS}

AMARAL, M. S.; MONTEIRO, D. A. A.; ALMEIDA, T. N. V. de. A natureza do conhecimento científico e a proposta da administração política. Revista Brasileira de Administração Política, v. 8, n. 1, p. 185-204, abr. 2015.

ARAUJO, S. V. Uma proposta para a consolidação da administração política no Brasil. Revista Brasileira de Administração Política, v. 5, n. 1, p. 119-135, out. 2012.

BARRETO, S. S. A construção da "administração política" e suas contribuições para a ciência da administração. Revista Brasileira de Administração Política, v. 4, n. 2, p. 77-97, abr. 2012.

BOTELHO, L. L. R.; CUNHA, C. C. de A.; MACEDO, M. O método da revisão integrativa nos estudos organizacionais. Gestão e Sociedade, v. 5, n. 11, p. 121-136, maio/ago. 2011.

BOYER, R. Économie politique des capitalismes: théorie de la régulation et des crises. Paris: Le Découvert, 2015. 
BURRELL, G.; MORGAN, G. Sociological paradigms and organizational analysis. London, UK: Heinemann, 1979.

CARIBÉ, D. Ciência ou ideologia? A constituição do campo da administração política. Revista Brasileira de Administração Política, v. 1, n. 1, p. 31-44, out. 2008.

COPI, I.; COHEN, C.; MCMAHON, K. Introduction to logic. Edinburgh, UK: Pearson, 2014.

CRISTALDO, R. C.; RIBEIRO, M. M.; PESSINA, M. E. H. Administração política e novo desenvolvimentismo: alternativas ou continuidade? Farol - Revista de Estudos Organizacionais e Sociedade, v. 4, n. 10, p. 601-663, ago. 2017. Disponível em: https://revistas.face.ufmg.br/index.php/farol/article/view/3923/2478. Acesso em: 25 maio 2019.

CWTS VOSviewer. Versão 1.6.14. Leiden, Hol.: Universiteit Leiden, 2020.

CUNHA, E. P. Centralidade da gestão e os limites da razão política: as contradições sociais como objeto real da gestão do Estado. In: Encontro de Administração Política, VII, 2016, Juiz de Fora, Anais. Juiz de Fora, ago. 2016. Disponível em:

https://administracaopolitica.wordpress.com/anais-2016/. Acesso em 15 jun, 2017.

CUNHA, E. P. Centralidade da gestão do Estado como limite da razão política ou para a crítica da administração política. Revista Eletrônica de Administração, v. 25, n. 2, p. 150-178, maio/ago. 2019. Disponível em: http://dx.doi.org/10.1590/1413-2311.237.809126. Acesso em: 20 set. 2019.

CUNHA, E. P. Ontogênese e formas particulares da função de direção: introdução aos fundamentos históricos para a crítica marxista da administração. In: CUNHA, E. P.; FERRAZ, D. L. Crítica marxista da administração. Rio de Janeiro: Rizoma, 2018. p. 13-67.

CUNHA, E. P.; GUEDES, L. T. Recepções do ideário marxista pelo pensamento administrativo: da oposição indireta à assimilação relativa. Organizações \& Sociedade, v. 24, n. 82, p. 432-455, jul./set. 2017. Disponível em: http://dx.doi.org/10.1590/1984-9240824. Acesso em: 01 jan. 2018.

DIETZ, Jan L. G. Enterprise ontology: theory and methodology. New York, US: Springer, 2006.

FRANÇA FILHO, G. C. de. Para um olhar epistemológico da administração: problematizando seu objeto. In: SANTOS, R. S. (Org.). A administração política como campo do conhecimento. São Paulo: Mandacaru, 2009. p. 123-147.

GALBRAITH, J. K. O novo estado industrial. Tradução de Leônidas G. de Carvalho. São Paulo: Nova Cultural, 1988. (Coleção Os Economistas). 
GRECO, John. Introdução: o que é epistemologia. In: GRECO, John; SOSA, Ernest (Org.). Compêndio de epistemologia. Tradução Alessandra S. Fernandes, Rogério Bettoni. São Paulo: Edições Loyola, 2012. p. 15-61.

GOMES, F. G. 0 jovem percurso da administração política. Revista de Administração Pública, v. 46, n. 1, p. 7-24, 2012. Disponível em: http://dspace/xmlui/bitstream/item/10033/5629.pdf. Acesso em: 10/07/2016.

GOMES, F. G. Fronteiras e contribuições da economia política para a administração política. In: Colóquio Internacional de Epistemologia e Sociologia da Ciência da Administração, V, 2015, Florianópolis. Anais [...]. Florianópolis: UFSC, 2015. Disponível em: http://coloquioepistemologia.com.br/site/wpcontent/uploads/2015/03/ANE1421228382.pdf. Acesso em 12 jan. 2017.

HODGSON, G. A evolução das instituições: uma agenda para pesquisa teórica futura. Tradução Jaques Kerstenetzky. Econômica, v. 3, n. 1, p. 97-125, jun. 2001.

JAPIASSÚ, H. F. Introdução ao pensamento epistemológico. 3.ed. Rio de Janeiro: Francisco Alves Editora, 1979.

KLIKAUER, T. Critical management as critique of management. Critical Sociology, v. 44, n. 4-5, p. 753-762, dez. 2016. Disponível em: https://doi.org/10.1177/0896920516683234. Acesso em: 29 ago. 2018.

KLIKAUER, T. Managerialism: a critique of an ideology. New York, EUA: Palgrave MacMillan, 2013.

KORTEN, D. C. When corporations rule the world. Berrett-Koehler Publishers, 2015.

KUHN, T. A estrutura das revoluções científicas. Tradução Beatriz V. Boeira, Nelson Boeira. 5.ed. São Paulo: Editora Perspectiva, 1998.

QSR NVivo. Versão 7.0.281.0. [S.l.]: QSR International, 2006. 1 CD.

MATTOS, Pedro Licoln C. L. de. "Administração é ciência ou arte?" O que podemos aprender com esse mal-entendido? Revista de Administração de Empresas, v. 49, n. 3, p. 349-360, jul./set. 2009.

MICROSOFT Excel. Versão 2016. [S.l.]: Microsoft Corporation, 2016. 1CD.

MINTZBERG, H. The nature of managerial work. New York, US: Harper \& Row, 1973.

MOREIRA, F. S. Administradores políticos enquanto classe: um projeto de pesquisa. Revista Brasileira de Administração Política, v. 1, n. 1, p. 45-66, out. 2008. 
NEWMAN, J.; CLARKE, J. Gerencialismo. Tradução Ananyr P. Fajardo. Educação \& Realidade, v. 37, n. 2, p. 353-381, maio/ago. 2012.

OLIVEIRA, I. T.; SANTANA, W. G. P. A administração política do comércio internacional: do livre comércio ao comércio estratégico administrado. Revista Brasileira de Administração Política, v. 2, n. 1, p. 101-126, abr. 2009.

PAULA, A. P. P. de. Para além dos paradigmas nos estudos organizacionais: o círculo das matrizes epistêmicas. Cadernos Ebape.Br, v. 14, n. 1, p. 26-46, jan./mar. 2016. Disponível em: http://dx.doi.org/10.1590/1679-395131419. Acesso em: 6 jan. 2017.

PINTO, F. L. B.; RIBEIRO, E. M. Administração política brasileira - novos objetos e novas abordagens: uma aproximação ao pensamento de Jorge Amado. In: Encontro da Associação Nacional de Pós-Graduação em Administração, XXXVIII, 2014, Rio de Janeiro. Anais [...]. Rio de Janeiro: Anpad, 2014. Disponível em: http://www.anpad.org.br/admin/pdf/ 2014_EnANPAD_EOR833.pdf. Acesso em 12 jan. 2017.

QUEIROZ, H. A. de. Administração política e Guerreiro Ramos: epistemologia e método. Revista Brasileira de Estudos Organizacionais, v. 2. n. 2, p. 263-287, dez. 2015. Disponível em: https://doi.org/10.21583/2447-4851.rbeo.2015.v2n2.56. Acesso em: 3 set. 2018.

RAMOS, A. G. A nova ciência das organizações. Tradução Mary Cardoso. 2. ed. Rio de Janeiro: Editora FGV, 1989.

REED, M. Teorização organizacional: um campo historicamente contestado. In: CLEGG, Stewart. et al. Handbook de estudos organizacionais. São Paulo: Atlas, 2012. v. 1. p. 61-97.

RIBEIRO, E. M. Revisitando o conceito de administração política. Revista Brasileira de Administração Política, v. 1, n. 1, p. 7-18, out. 2008.

SANTOS, E. L. et al. Contribuições da administração política para o campo da administração. Revista Interdisciplinar de Gestão Social, v. 3, n. 3, p. 183-200, maio/ago. 2014. Disponível em: http://dx.doi.org/10.9771/23172428rigs.v3i2.9894. Acesso em: 3 set. 2018.

SANTOS, E. L. et al. Administração política: ensino, pesquisa e prática. Farol - Revista de Estudos Organizacionais e Sociedade, v. 4, n. 10, p. 506-524, ago. 2017. Disponível em: https://revistas.face.ufmg.br/index.php/farol/article/view/4217/2476. Acesso em: 3 set. 2018.

SANTOS, E. L.; SANTOS, R. S.; BRAGA, V. L. O campo científico da administração: percursos e percalços. Colóquio Internacional de Epistemologia e Sociologia da Ciência da Administração, IV. Florianópolis, 2014, Anais. Disponível em: http://coloquioepistemologia.com.br/site/wpcontent/uploads/2014/04/ANE-124-O-CAMPO-CIENT\%C3\%8DFICO-DA-

ADMINISTRA\%C3\%87\%C3\%830.pdf. Acesso em: 2 set. 2017. 
SANTOS, E. L. Teoria da administração política do desenvolvimento: uma proposta teórica do Sul. In:___. (Org). Teorias administrativas contemporâneas: diálogos e convivência. Vitória da Conquista ; São Paulo: Edições Uesb ; Hucitec, 2016.

SANTOS, R. S. et al. A crise, o Estado e os equívocos da administração política do capitalismo contemporâneo. Cadernos Ebape.Br, v. 14, n. 4, out./dez. 2016. Disponível em: http://dx.doi.org/10.1590/1679-395130795. Acesso em: 18 mar. 2018.

SANTOS, R. S. et al. Administração política e políticas públicas: em busca de uma nova abordagem teórico-metodológica para a (re)interpretação das relações sociais de produção, circulação e distribuição. Cadernos Ebape.Br, v. 15, n. 4, out./dez. 2017. Disponível em: http://dx.doi.org/10.1590/1679-395155017. Acesso em: 18 mar. 2018.

SANTOS, R. S. Em busca da apreensão de um conceito para administração política. Revista de Administração Pública, v. 35, n. 5, p. 49-77, set./out. 2001.

SANTOS, R. S. A administração política como campo do conhecimento. São Paulo: Mandacaru, 2009a.

SANTOS, R. S. As contribuições dos economistas ao estudo da administração política: o institucionalismo, o gerencialismo e o regulacionismo. In: (Org.). A administração política como campo de conhecimento. São Paulo: Mandacaru, 2009b. p. 62-93.

SANTOS, R. S. Keynes e a proposta de administração política para o capitalismo: uma crítica aos pressupostos da externalidade do Estado e da crise fiscal. São Paulo: Hucitec, 2010a.

SANTOS, R. S. Manifesto da administração política para o desenvolvimento do Brasil. (Garanhuns - PE). Mimeo. Salvador, janeiro de 2010b.

SANTOS, R. S.; GOMES, F. G. Outro modo de interpretar o Brasil. Agência Carta Maior. 14 fev. 2017. Disponível em: https://www.cartamaior.com.br/?/Editoria/Economia-Politica/Outromodo-de-interpretar-o-Brasil/7/37705. Acesso em: 30 mar. 2018.

SANTOS, R. S.; RIBEIRO, E. M. A administração política brasileira. Revista de Administração Pública, v. 27, n. 4, p. 919-41, out./dez. 1993. Disponível em:

http://dx.doi.org/10.1590/1679-395155017. Acesso em: 15 ago. 2011.

SANTOS, R. S.; RIBEIRO, E. M.; SANTOS, T. C. Bases teórico-metodológicas da administração política. Revista de Administração Pública, v. 43 n. 4, p. 919-41, jul./ago. 2009. Disponível em: http://dx.doi.org/10.1590/S0034-76122009000400008. Acesso em: 15 ago. 2011.

SANTOS, R. S. et al. A crise, o estado e os equívocos da administração política do capitalismo contemporâneo. In: Encontro de Economia Política, XVIII, 2013, Belo Horizonte. Anais [...]. 
Gragoatá, RJ: Sociedade Brasileira de Economia Política, 2013. Disponível em: http://www.sep.org.br/artigos/download?id=2260. Acesso em: 1 set. 2016.

TRAGTENBERG, M. Administração, ideologia e poder. Campinas: Ed. Unesp, 2005 